\title{
Drinking water quality: stakes of control and sanitation in the town of Dschang - Cameroon
}

\author{
Emile TEMGOUA $^{1 *}$, Emmanuel NGNIKAM ${ }^{2}$ and Barthélémy NDONGSON ${ }^{3}$ \\ ${ }^{1}$ University of Dschang, Faculty of Agronomy and Agricultural Science, PO Box 222 Dschang, Cameroon. \\ ${ }^{2}$ Laboratoire Environnement et Science de l'Eau, ENSP, BP 8390 Yaoundé, Cameroun. \\ ${ }^{3}$ Services Techniques, Commune de Dschang, BP 169 Dschang, Cameroun. \\ *Corresponding author, E-mail: emile.temgoua@univ-dschang.com; \\ Tel: +23777013564; Fax + 23733451381
}

\begin{abstract}
The present study aims to present a complete diagnosis of the state of water supply and sanitation in the Dschang city. After an inventory of the actor practices starting from existing documentations of the Dschang urban council, 87,000 inhabitants, we identified consumers through physical field identification of the water supplies and sanitation in November 2007. All wells were mapped, 300 households surveyed and water quality analysed. It appears that water is basically supplied through connection on the conventional "CAMWATER" network. Over 52.2\% of households not connected to network used 728 alternative points for water assessment (705 wells and 23 springs), and drawn drinking water especially from springs. Bacteriological quality varies greatly from one water point to another. Water coming from depth soils and managed water points are relatively more improved in quality. For the 250 sanitation installations surveyed, $70 \%$ of households use pit latrines with open bottom; 116 latrines are located in a radius of $15 \mathrm{~m}$ around the wells and springs. For the wastewater drainage and treatment, no device is constructed. The difficulties of supplying safe drinking water and the precarious conditions of sanitation seemed to be the origin of many water borne-diseases in this city.

(C) 2009 International Formulae Group. All rights reserved.
\end{abstract}

Keywords: Water supply points, Individual toilet sanitation, Conventional network, Alternative suppliers, Water borne-diseases.

\section{INTRODUCTION}

Agriculture is the main activity of inhabitants of West Cameroon in general and Dschang in particular. However, following the expansion of Dschang town over time, many urban activities are being noticed. By decree $N^{\circ}$ 2007/117 of April 24, 2007, the President of the Republic of Cameroon combined the former Dschang Urban Council and Dschang Rural Council to a unique Dschang Council (Figure 1). The former Dschang urban council covered approximately $16.5 \mathrm{~km}^{2}$ with more than 87,000 inhabitants (INS, 2005) and was since 1935, an important touristic site in the country. The urbanisation process and cosmopolitan nature of Dschang was further accelerated in 1993 when it became a University town, receiving 8,000-10,000 new individuals each year. This has lead to over 75\% increase in living expenses, an anarchic occupation of spaces and archaic building systems of low quality mini halls of residence. Furthermore, waste disposal and provision of drinking water at homes has since been major concerns. Many studies in African cities report that: Wells, rivers and springs are ubiquitously used for water supply; many pit 

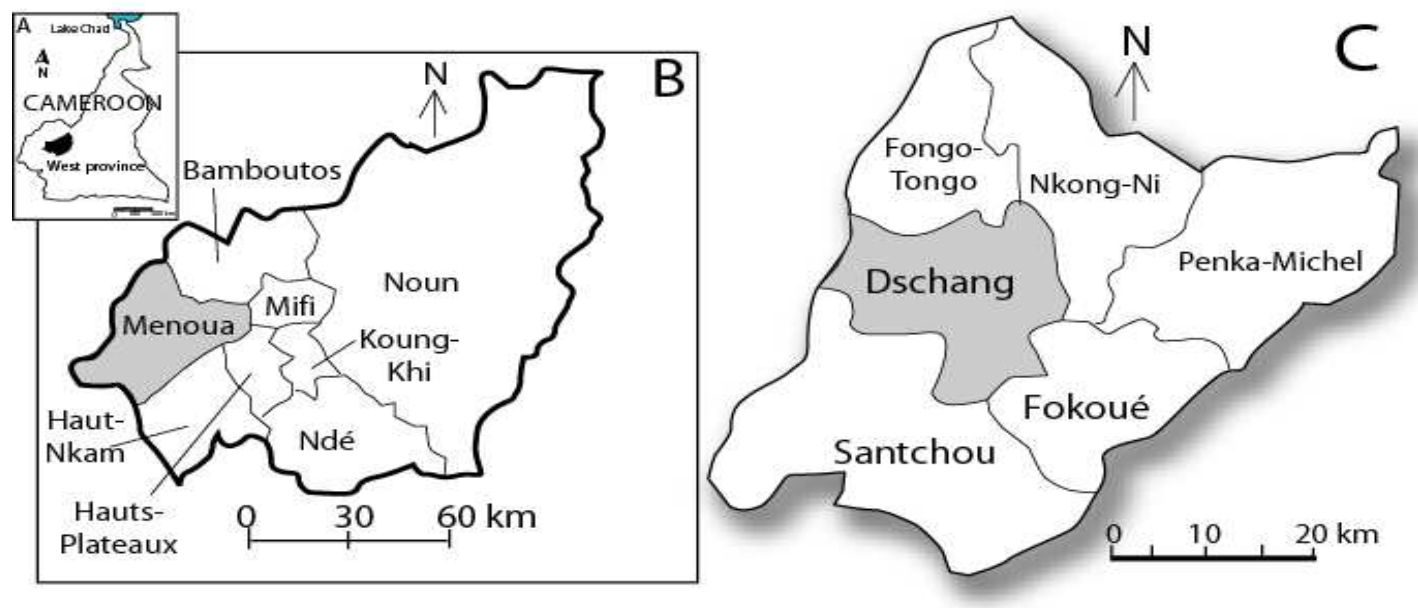

Figure 1: The Dschang Council located in the Menoua Division (C), in the West Province (B) and in Cameroon (A).

latrines present an open bottom and can create localised saturated flow conditions that imply great risks of using groundwater (Tanawa, 2002; Tanawa et al., 2002; Temgoua, 2006). The present study aims to diagnose the state of water supply and sanitation in the Dschang Urban Council area.

\section{MATERIALS AND METHODS}

Retrospective studies and field surveys to determine water supply sources, network and sanitation were carried out. Existing drinking water structures, sanitary and quality control measures were studied. The general cartography of drinking water supply in the city was carried out by a superposition of the thematic maps drawn from various types of water and sanitation structures. A total of 300 households, chosen according to a stratified surveyed method, were investigated to evaluate the level of services provided and satisfaction of liquid waste disposal systems. Detailed water quality analyses through the determination of physico-chemical and bacteriological characteristics in situ and in the 'Laboratoire d'Analyses des Sols et de Chimie de l'Environnement (LABASCE)', of the Dschang University were carried out.

The physico-chemical and bacteriological characteristics of water were analysed as follows:

- pH: WTW 325 pH meter - field measurement;
- Conductivity/temperature: WTW LF318 conductimeter - field measurement;

- Ammoniacal nitrogen: Spectrophotometer (box Hach DR2000) - Method of NESSLER;

- DBO5: box HACH BODtrak: Incubation at $20{ }^{\circ} \mathrm{C}$ during 5 days and reading height of the mercury columns ;

- Faecal coliform and faecal streptococci: for the coliforms, the lactosed agar with TTC and tergitol were used as culture medium, while the agar with bile, esculine and sodium acid were used for the faecal streptococci.

\section{RESULTS}

Water supply in the city

The water supplying networks and water communities' infrastructures in Dschang town are presented in figure 2.

«CAMWATER», a national conventional water network supply, covers $27 \%$ (36 $\mathrm{km}$ ) of land and serves $32.5 \%$ of households. The rates of connection to the network vary enormously from one hamlet to another. For the over 87,000 inhabitants in about 14,000 household (UN-Habitat, 2005) in the town, only 2,675 were subscribed to the «CAMWATER» network. The price of network connection is 73,125 Francs CFA (112 euro) for a pipe of $15 \mathrm{~mm}$ diameter and less than $5 \mathrm{~m}$ length; it is necessary to add 2,705 francs for each additional meter, 19,205 francs in advance of consumption, 


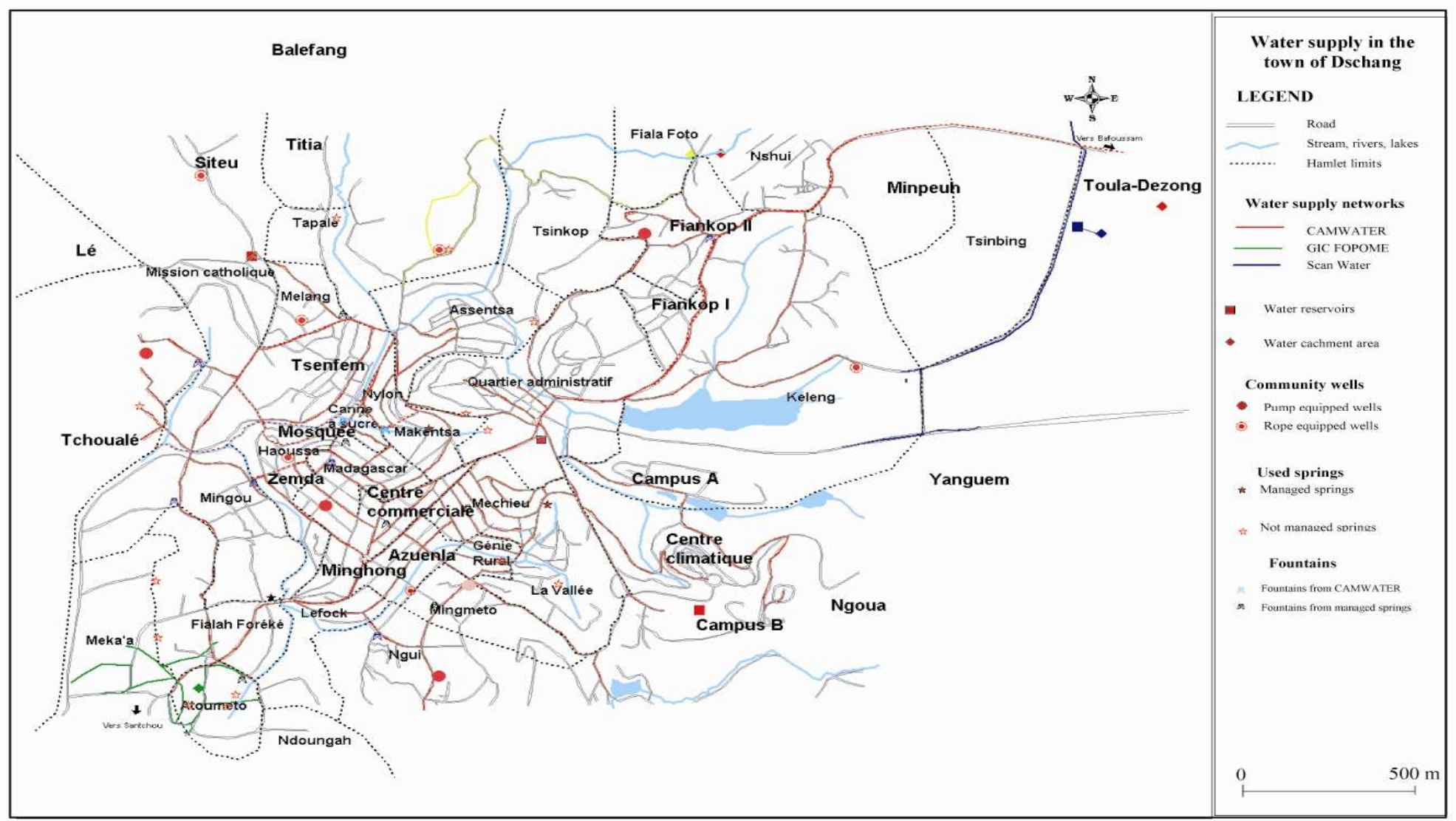

Figure 2: Water supply networks and water communities' infrastructures in the town of Dschang. 
and 4,535 francs of expenses for installation of water meter, and also taking into account time between request and connection. This connexion price is high for the average income households (less than 50,000 francs CFA, 76 euro, per month for an average of 08 peer household). The materials of the network are also old and are exhumed very often by erosion; what causes frequent cuts.

As for private networks, "GIC FOPOME" at Foréké-Dschang quarter covers $9 \mathrm{~km}$ with 78 subscribers while "Scan Water" at Tsinbing quarter covers $4 \mathrm{~km}$ and had 124 subscribers.

The alternative water supply points recorded (table 1): 705 wells (694 private and 11 community wells, with 10 built by the Dschang Urban Council), 23 springs (with 3 springs managed by the Dschang urban Council) and 19 fountains are assuring water supply for $52.2 \%$ of household surveyed.

Private water supply networks/points were also recorded including that of motel "Centre Climatique", Catholic Reverent Sister community, and «CAMWATER» subscribers who served as sources for households who cannot afford direct subscription or trade in water. $15.3 \%$ of households not connected consume water from the network. Other not connected households use water from wells $(92.9 \%)$ and springs $(3 \%)$. For this category, $45.5 \%$ draw drinking water from spring. For the users of pipe-borne water and those who are supplied from private sources, a litre of water cost 10 francs CFA, twice more expensive.

\section{Water quality}

The physico-chemical and bacteriological characteristics of the water are presented in table 2 . They result from various environmental sites that a statistical analysis would not bring any complementary information. Water from points in Dschang was acidic, with the surface water being more basic than deep water. All points were used as drinking water and otherwise. The bacteriological quality (faecal coliforms, streptococci and $\mathrm{NH}_{4}$ ) of this water varies from one point to another. There was slight difference between surface water (LVS, SAS) and water coming from basement (PSS, MIS, MAS). Basement waters were relatively of improved quality. The physico-chemical quality was poor but could be improved after management. Turbidity was higher in water from streams although some springs had also abundant suspended particles.

\section{Sanitation}

The sanitation in this study concerns liquid waste and excreta, which to the service providers was not problematic. Nonetheless, many households complained of grey water stagnation on roadsides and gutters during the dry season. All households in the city were equipped with toilets for passage of excreta. About $70 \%$ of the toilets (out of 250 toilets) were traditional latrines while the rest $(30 \%)$ were modern toilets; 116 latrines were located at a radius of $15 \mathrm{~m}$ around drinking wells and springs. Actually, households located in the same concession shared latrines. On average, a well or spring could be surrounded by 2 latrines. The pit latrines are generally dug to water table level, poorly structured and do not respect standards (e.g. number of inhabitants per household). Failing to drain or dig another pit, households use carbide to reduce the level of excreta.

The town council is not equipped with any excreta or liquid waste draining and management device. The waste when it is successfully drained is poured (table 3 ) into channels, farm, gutters or on unoccupied farm lands.

Draining machines are found in distant Bafoussam and Douala towns $(60 \mathrm{~km}$ and 350 $\mathrm{km}$ from Dschang respectively) and frequent requests for draining were from hospitals, prison, market A, student hostels and hotels. The removal of mud and other waste matter of draining were generally carried out without any sanitary control neither of the places, nor of the conditions of handling.

Table 1: Different alternative water supply points in Dschang city in 2007.

\begin{tabular}{lcc}
\hline Type & Number & Percentage \\
\hline Fountains & 19 & 2.5 \\
Community wells & 11 & 1.5 \\
Private wells & 694 & 92.9 \\
Used springs & 23 & 3.1 \\
\hline Total & $\mathbf{7 4 7}$ & $\mathbf{1 0 0}$ \\
\hline
\end{tabular}


Table 2: Water physico-chemical and bacteriological analysis of Dschang town (November 2007).

\begin{tabular}{|c|c|c|c|c|c|c|c|}
\hline & SAS & PSS & CES & RUS & MIS & $\mathbf{L V S}^{* * *}$ & MAS $^{* * *}$ \\
\hline Turbidity (FTU) & 34.00 & 4.00 & 28.00 & 53.00 & 3.00 & - & - \\
\hline Suspended particles (mg/l) & 56.00 & 7.00 & 9.00 & 17.00 & 5.00 & - & - \\
\hline Conductivity $(\mu \mathrm{S} / \mathrm{cm})$ & 43.1 & 14.7 & 27.2 & 37.3 & 15.6 & - & - \\
\hline Temperature $\left({ }^{\circ} \mathrm{C}\right)$ & 21.2 & 21.2 & 19.0 & 20.1 & 20.0 & 22.4 & 23.6 \\
\hline $\mathrm{NO}_{3}{ }^{-}(\mathrm{mg} / \mathrm{l})$ & 0.80 & 0.80 & 5.00 & 5.40 & 0.45 & - & - \\
\hline $\mathrm{PO}_{4}{ }^{3-}(\mathrm{mg} / \mathrm{l})$ & 0.32 & 1.98 & 2.30 & 0.40 & 0.30 & - & - \\
\hline $\mathrm{pH}$ & 5.57 & 5.20 & 6.76 & 6.63 & 5.30 & 6.2 & 5.15 \\
\hline $\mathrm{Eh}(\mathrm{mV})^{*}$ & 91 & 144 & 25 & 30 & 150 & - & - \\
\hline $\mathrm{DBO}_{5}(\mathrm{mg} / \mathrm{l})$ & 28 & 23 & 22 & 20 & 20 & - & - \\
\hline $\mathrm{NH}_{4}^{+}(\mathrm{mg} / \mathrm{l})$ & 0.14 & 0.16 & 0.45 & 0.38 & 0.15 & - & - \\
\hline Faecal coliforms (UFC/100 ml) & 8 & 20 & 13 & 15 & 10 & 1600 & 13 \\
\hline Faecal streptococci (UFC/100 ml) & 2 & 10 & 5 & 5 & 1 & 200 & 1 \\
\hline
\end{tabular}

SAS: Slightly managed spring at Siteu; PSS: slightly managed well at Siteu; CES: Tatchou stream; RUS: stream from SAS spring; MIS: Stocked water from drilling at Catholic Reverent Sister Community, - not analysed. * Not corrected values. ** From Da Costa (2004): LVS: La Vallée not managed spring, MAS: Madagascar managed spring.

Table 3: Different places of wastewater drainage in Dschang (November 2007).

\begin{tabular}{lcc}
\hline $\begin{array}{l}\text { Place of waste } \\
\text { water drainage }\end{array}$ & Total & Percentage \\
\hline Town channel & 141 & 56.4 \\
Farm & 64 & 25.6 \\
House yard & 16 & 6.4 \\
Septic tanks & 29 & 11.6 \\
\hline Total & $\mathbf{2 5 0}$ & $\mathbf{1 0 0}$ \\
\hline
\end{tabular}

Although the council abattoir is located near a waterfall and also connected to «CAMWATER» network, its hygienic state leaves much to be desired. There is neither electricity supply there nor cold room, but animals for consumption are slaughtered daily; cattle: 5-10; pig: 3-5 and horses: 2-4. Waste matter and liquid from the abattoir are directly flushed into the nearby river, streams and valley used for urban agriculture and human habitat.

The city has 3 markets which are not supplied with drinking water and poorly drained resulting in flooding each time it rains in the area.

Wastewaters are poured today into the stream, soil and underground. The low wetting lands, usually used for urban agriculture and for human habitat are now the receptacle of waste from households, markets and abattoir. Also, wells, springs, streams and rivers used for drinking water are bordered by traditional latrines, abattoir and markets and are exposed to pollution.

\section{DISCUSSION}

In November 2007, Da Coasta (2004) and Era-Cameroun (2005) were the only reports on water services and sanitation in the town of Dschang.

Dschang does not suffer from hydrous deficit because of a very long rainy season $(1,750 \mathrm{~mm}$ of rain per year) that supplies the aquifer. Yet the access to drinking water is expensive, and more for the poor populations than for most affluent and moreover the costs of connection are not within their reach. Indeed, to have access to "CAMWATER" network, a minimum of 100,000 FCFA (150 euro) is necessary. Unfortunately, those who cannot afford for connection must buy water more expensive from the neighbour or from fountains. Those who cannot buy pipe-borne water, carry water from springs for the majority or from wells.

Water analyses usually provided by "CAMWATER" present the water they supply as limpid, colourless and odourless. However, this is contrary to the finding of Da Costa (2004) who observed trapped muddy particles when one litre of "CAMWATER" water was filtered through a cotton pack. Many biologists issue reserves in connection with the turbidity of water. Coloured "CAMWATER" water is considered drinkable. The presence of faecal coliforms or other pathogenic agents either related to faecal 
pollution of water or otherwise is dangerous for public health (European Union, 1998; WHO, 2004), thus such waters should not be consumed. However, water containing less than 20 Units CF per $100 \mathrm{ml}$ as is the case in Sub-Saharan Africa (LESEAU, 1998), is considered to be of good quality. This standard was used to qualify Dschang water. Water from alternative sources presented relatively good quality, and was polluted only when the infrastructures were not well managed. This is in conformity with the findings of Tanawa et al. (2002) who showed that complementary methods, notably wells and springs may be validly conciliated with thinkable protection measures.

Accelerated urbanisation, increase population and touristic activities indicate more water consumption to the town (Temgoua, 2006; Boon, 2008). However, only $32.5 \%$ of household are connected to conventional network. Also, over $52.2 \%$ of households not connected use only water from wells or springs. Pathogenic microbes can move vertically and laterally in the soil (Majdoub et al., 2003). The problems of rate and distance of contamination is widespread but unresolved in Sub-Saharan African cities (Strauss, 2000; Tanawa, 2002) and further complicated by the multiplicity of soil purifying capacity (Temgoua et al., 2005). In the poor urban environment context of Dschang town, alternative water points are near latrines and uncontrolled rubbish bin. Thus certain water points are polluted and others not.

For the UN-Habitat (2005), difficulties in the supply of drinking water in Dschang and the precarious conditions of sanitation are at the origin of diseases such as amoebiasis, helminthiasis, typhoid fever and diarrhoea. The study of Boon (2008) reported that, 19\% of the patients suffering from water-borne diseases (helminthiasis: 7.2\%, typhoid: $6 \%$, amoebic diarrhoea/dysentery: $4.9 \%$, intestinal fungi: $0.7 \%$ ) on a whole 8,000 patients found in the hospitals, pharmacies and in the traditional practitioners of the city.

\section{Conclusion and outlook}

The question of water supply and sanitation is a topical question in Dschang. Few studies have been carried out to deal with problems related to water supply and sanitation. Information search showed lack of documents on the subject. Dschang naturally does not suffer from hydrous deficit because of long rainy seasons. However, the high cost of subscribing to the conventional water supply network and frequent dysfunctions in the network support the development of alternative drinking water sources.

In 2007, Dschang town accounted for approximately 728 alternative water points for over $52.2 \%$ of households not connected to the network. 116 latrines were located at a radius of $15 \mathrm{~m}$ around drinking wells and springs. In 2008, using the results from assess water diagnosis (Era-Cameroun, 2005; this study), the International association of the French-speaking Mayors (AIMF) financed the management of 19 other water points (12 springs and 07 wells) in the present Dschang Council. Certain water points are polluted and others not. One wonders about the physical characteristics (natural of the underground, depth and fluctuations of water table level) and techniques (structure and position of sanitation device) of non-polluted points, which prevent transfer of pollutants into the water points. In order to help the municipality use wells for drinking water and proscribe those which have poor water quality, bacteriological and physico-chemical analyses should be carried out on all of these water points.

Future research on the health risks posed by groundwater contaminations from pit latrines in swampy zones, near drinking water points is therefore very important. The study will focus on soil capacity to purify microbiological agents and transfer of chemical pollutants.

Our wish for the immediate future is:

1) To evaluate, qualitatively and quantitatively, the principal contaminants (chemical and bacteriological), critical places, and to relate them to the characteristics of the drainage systems and properties of the soils;

2) To determine the distance and direction of transfer of these pollutants.

\section{ACKNOWLEDGEMENTS}

The authors are grateful to the International Foundation for Science for the research grant (Grant W/4206-1) and financial support to attend CSRS International Scientific Conference in Abidjan. We also 
appreciate Dr NDUKUM of the University of Dschang for proofreading this paper.

\section{REFERENCES}

Boon N. 2008. Environmental burden of water borne disease in Dschang, Western Province-Cameroon: Health impacts and causal factors. Breaking Ground Report, $34 p$.

Da Costa A. 2004. L'approvisionnement en eau potable des populations de la ville de Dschang. Mémoire de Maîtrise de Géographie, Université de Bordeaux III.

ERA-Cameroun, 2005. Diagnostic de l'approvisionnement en eau et de l'assainissement dans la ville de Dschang. CUD, 107p. et annexes.

European Union. 1998. Directive du conseil 98/83/EC sur la qualité de l'eau attendue pour la consommation humaine. Directive adoptée le 3 Novembre 1998. European Union.

INS. 2005. Annuaire statistique du Cameroun 2004. Institut National de Statistique.

LESEAU. 1998. Gestion de l'Eau et Protection de la Ressource (GEPRE). Rapport de recherche conduit par le Laboratoire Environnement et Sciences de l'Eau sous la Coordination de Emile Tanawa. Document available at ENSP of Yaoundé and online at http://www.gret.org/pseau, 183p.

Majdoub R, Côté C, Labidi M, Guay K, Généreux M. 2003. Revue de littérature: impact de l'utilisation des engrais de ferme sur la qualité microbiologique de l'eau souterraine. Rapport IRDA, Québec, $140 \mathrm{p}$.

Strauss M. 2000. Human Waste (Excreta and Wastewater) Reuse. EAWAG/SANDEC; $31 \mathrm{p}$.

Tanawa E. 2002. Gestion et valorisation des eaux usées dans les zones à habitat planifié et leurs périphéries. Rapport LESEAU / ENSP Yaoundé Cameroun / Equipe Développement Urbain INSA de Lyon sept. 2002.

Tanawa E, Djeuda Tchapnga HB, Ngnikam E, Temgoua E, Siakeu J. 2002. Habitat and protection of water resources in suburban areas in african cities. Building and Environment, 37(3): 269-275.

Temgoua E. 2006. Etude environnementale sommaire pour l'implantation de la décharge municipale à Siteu - Dschang. Rapport final, Laboratoire d'Analyses des sols et de Chimie de l'Environnement (LABASCE), Univ. Dschang, 31p.

Temgoua E, Djeuda Tchapnga HB, Tanawa E, Guenat C, Pfeifer HR. 2005. Ground water fluctuations and footslope soil genesis in the humid tropical zone of Southern Cameroon. Hydrological Processes, 19(16): 3097-3111.

UN-HABITAT, 2005. Municipalité de Dschang: une ville au passé glorieux face aux nouveaux défis. UN-HABITAT.

WHO, 2004. Guidelines for Drinking-water Quality Recom-mendations (Vol 1; $3^{\text {rd }}$ edn). WHO: Geneva; 540 p. 